\title{
Ameliorative Effect of Quercetin against Modification Induced by 5-Fluorouracil on Alpha-2-Macroglobulin
}

\author{
Syed Saqib Ali ${ }^{1}$, Haseeb Ahsan ${ }^{2}$, Sana Ansari ${ }^{1}$, Fahim Halim Khan ${ }^{1, *}$
}

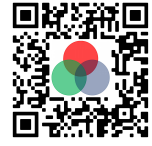

Use your smartphone to scan this QR code and download this article

\begin{abstract}
Introduction: Alpha-2-macroglobulin $\left(\alpha_{2} \mathrm{M}\right)$ is large glycoprotein, found in the plasma of vertebrates and invertebrates, which plays a major role in regulation and transport. In this study, we report the interaction of 5-fluorouracil (5-FU) with $\alpha_{2} \mathrm{M}$ and the protective effect of quercetin against 5-FU induced modification of $\alpha_{2}$ M. Methods: Various biochemical and biophysical methods and techniques were employed to determine the binding interaction between $\alpha_{2} \mathrm{M}-5$-FU and the preventive effect of quercetin on 5-FU induced modification of $\alpha_{2} \mathrm{M}$. Fluorescence microscopy was performed to analyze the formation of free radicals by 5-FU and to examine the scavenging effect of quercetin. Results: Our results of antiproteinase activity assay show that the $5-\mathrm{FU}-\alpha_{2} \mathrm{M}$ interaction causes functional inactivation of sheep $\alpha_{2} \mathrm{M}$, while the $5-\mathrm{FU}-\alpha_{2} \mathrm{M}$ complex after exposure to quercetin regains its native conformation. Intrinsic fluorescence results suggest an increase of 5-FU quenching in the fluorescence intensity, and when the mixture was incubated with quercetin the $\alpha_{2} \mathrm{M}$-FU-quercetin mixture showed the same intensity as that of native protein. The absorption spectra of 5-FU- $\alpha_{2} \mathrm{M}$ complex suggest the formation of a complex leading to increase in absorbance. CD and FTIR spectroscopy show 5-FU causes secondary structural alteration of $\alpha_{2} \mathrm{M}$ and quercetin provides a protective role against structural modification. Conclusion: Our study suggests that 5-FU produces reactive oxygen species (ROS) in the presence of light and compromises the integrity of $\alpha_{2} \mathrm{M}$. Quercetin quenches the ROS formed by 5-FU and helps the protein to maintain its native conformation. We have demonstrated the protective effect of quercetin for the first time against the toxicity induced by 5-FU on $\alpha_{2} \mathrm{M}$.
\end{abstract}

Key words: 5-Fluorouracil, alpha-2-macroglobulin, circular dichorism, flavonoids, FTIR, quercetin, reactive oxygen species

${ }^{1}$ Department of Biochemistry, Faculty of Life Sciences, Aligarh Muslim University, Aligarh - 202002, India

${ }^{2}$ Department of Biochemistry, Faculty of Dentistry, Jamia Millia Islamia, New Delhi - 110025, India

\section{Correspondence}

Fahim Halim Khan, Department of Biochemistry, Faculty of Life Sciences, Aligarh Muslim University, Aligarh 202002, India

Email: fahimhkhan@rediffmail.com

\section{History}

- Received: Oct 02, 2021

- Accepted: Dec 03, 2021

- Published: Dec 30, 2021

DOI : 10.15419/bmrat.v8i12.711

\section{Check for updates}

\section{Copyright}

(c) Biomedpress. This is an openaccess article distributed under the terms of the Creative Commons Attribution 4.0 International license.

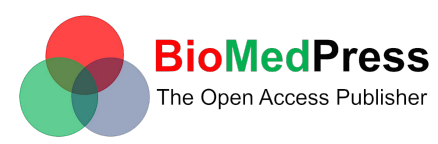

\section{INTRODUCTION}

5-fluorouracil (5-FU), a fluorinated pyrimidine analogue, is an anticancer drug and is an analogue of uracil containing fluorine at $\mathrm{C}-5$ position instead of hydrogen atom ${ }^{1}$. 5-FU can be incorporated into DNA and RNA due its structure and the fact that it interferes with nucleoside metabolism, which may lead to cell death and cytotoxicity ${ }^{2}$. 5-FU is found to be a beneficial drug used for the treatment of tumours of the head, breast and neck ${ }^{3}$. It is also an effective drug to treat cancers of the gastrointestinal tract, stomach, cervix and colon ${ }^{4-7}$. However, it is also associated with toxicity, the most common being acute coronary syndrome $^{8,9}$, and the administration of 5-FU to humans can induce cardiotoxic effects such as cardiomyopathy and vasospastic angina ${ }^{10-14}$. The interaction of anticancer drugs with proteins is very effective in pharmacology and is considered to be important for the administration of drugs in the human body. Sheep alpha-2-macroglobulin $\left(\alpha_{2} \mathrm{M}\right)$ is a large tetrameric glycoprotein of $630 \mathrm{kDa}^{15}$, containing identical subunits joined by non-covalent disulphide bonds $\mathbf{1 6}^{\mathbf{1}} \mathbf{1 7}$. The $\alpha_{2} \mathrm{M}$ has been isolated from various sources such as haemolymph of invertebrates, plasma of vertebrates and the egg white of birds and reptiles $^{\mathbf{1 8 - 2 2}}$. It is a major antiproteinase found in the blood and tissues and binds to various cytokines and growth factors ${ }^{23}$ and is also responsible for the binding and transport of human growth hormone ${ }^{24}$. It is a classic proteinase inhibitor and can inhibit all proteinases irrespective of their specificity and catalytic mechanism ${ }^{\mathbf{2 5 , 2 6}}$; however, it does not inactivate them, which makes it unique. After inhibition, it obstructs the entry of substrates (large molecular weight) to the active site ${ }^{27}$.

Flavonoids are the compounds of plant origin and possess antioxidant and anti-inflammatory properties. Quercetin provides a protective effect against free radicals and also plays a vital role in the reduction of oxidative stress ${ }^{28-32}$. The aim of this study is to investigate the antioxidant effect of quercetin and its protective effect on 5-FU-induced modification of $\alpha_{2} \mathrm{M}$. Several studies show that 5-FU produces 
free radicals in the presence of light, which disrupts the integrity of proteins ${ }^{32-37}$. When 5 -FU interacts with $\alpha_{2} \mathrm{M}$ in the presence of light it induces a change in $\alpha_{2} \mathrm{M}$ both structurally and functionally. In the present study, we provide evidence for the binding of 5-FU with $\alpha_{2} \mathrm{M}$. Moreover, we also provide information regarding the protective effect of quercetin against the toxicity induced by 5 -FU on $\alpha_{2} \mathrm{M}$.

\section{METHODS}

\section{Materials}

Trypsin, soya bean trypsin inhibitor (STI), NBenzoyl-DL-arginine-p-nitroanilide (BAPNA) and Sephacryl 300HR, quercetin, 5-FU and quercetin were obtained from Sigma-Aldrich, India. All reagents used were analytical grade and commercially available.

\section{Methods \\ $\alpha_{2}$ M antiproteinase activity}

To analyse the change in the functionality of $\alpha_{2} \mathrm{M}$, antiproteinase assay was performed. The activity profile of protein was measured with increasing concentrations of 5-FU in the presence of light. To determine the protective effect of quercetin, it was preincubated with protein and then treated with $5-\mathrm{FU}^{38}$. The reaction mixture consisted of $1 \mathrm{ml}$ sample in $50 \mathrm{mM}$ sodium phosphate buffer ( $\mathrm{pH} \mathrm{7.4)}$ at room temperature $\left(22 \pm 1^{0} \mathrm{C}\right)$. After incubation for $1 \mathrm{hr}$, $0.161 \mathrm{nmol}$ trypsin was added into the mixture and incubated for $15 \mathrm{~min}$ at $37^{\circ} \mathrm{C}$. After $15 \mathrm{~min}$ incubation, $0.45 \mathrm{nmol}$ of soybean trypsin inhibitor (STI) was added into the reaction mixture and the incubation was continued for additional $15 \mathrm{~min}$ at $37^{\circ} \mathrm{C}$. Finally, $2.28 \mu \mathrm{mol}$ of N-Benzoyl-DL-arginine-p-nitroanilide (BAPNA) was added and absorbance was observed at $410 \mathrm{~nm}$.

\section{Intrinsic fluorescence measurements}

The fluorescence spectra for native $\alpha_{2} \mathrm{M}$ and 5-FU and quercetin were recorded on a Shimadzu RF-5301 spectrofluorometer (Tokyo, Japan) in a $10 \mathrm{~mm}$ path length quartz cell. The excitation wavelength was set at $280 \mathrm{~nm}$ and the emission spectra were recorded in the range of 300-400. The concentration of protein in the sample was $10 \mu \mathrm{M}$ with varying concentration of 5 -FU and the concentration of quercetin was $50 \mu \mathrm{M}$ in the aliquot.

\section{Synchronous fluorescence analysis}

Synchronous fluorescence was recorded on a Shimadzu RF5301 spectrofluorophotometer, Japan. The wavelength range $(250-400 \mathrm{~nm})$ of fluorescence spectra selected for synchronous scanning was recorded at $\Delta \lambda$ of $15 \mathrm{~nm}$ and $60 \mathrm{~nm}$ for tyrosine and tryptophan, respectively.

\section{UV absorption spectroscopy}

UV spectrum of native $\alpha_{2} \mathrm{M}(10 \mu \mathrm{M})$ and $\alpha_{2} \mathrm{M}$ incubated with quercetin $(50 \mu \mathrm{M})$ with increasing concentration of 5-FU were recorded between $250-350 \mathrm{~nm}$ on a Shimadzu UV visible Spectrophotometer UV1700 using a cuvette of $1 \mathrm{~cm}$ path length ${ }^{39}$.

\section{FTIR spectroscopy}

FTIR spectroscopy was performed on an Interspec 2020 FTIR spectrometer. The samples were prepared by dissolving native $\alpha_{2} \mathrm{M}(20 \mu \mathrm{M})$ and $\alpha_{2} \mathrm{M}$ incubated with quercetin and $5-\mathrm{FU}$ in $20 \mathrm{mM}$ sodium phosphate buffer, $\mathrm{pH}$ 7.4. The spectra of native $\alpha_{2} \mathrm{M}$ incubated with varying concentration of 5-FU and quercetin $(50 \mu \mathrm{M})$ were analyzed. Amide I (1600 $1700 \mathrm{~cm}^{-1}$ ) is the region which is usually analyzed to confirm the change in the native structure of the protein. The scanning wave number was $1000-4000$ $\mathrm{cm}^{-140}$.

\section{CD measurements}

CD measurements were recorded on a JASCOJ815 spectropolarimeter equipped with a Peltiertemperature controller. Wavelength scan for native $\alpha_{2} \mathrm{M}(20 \mu \mathrm{M})$ and quercetin with varying concentration of 5-FU were carried out. The temperature was maintained at $25^{\circ} \mathrm{C}$ and the speed was fixed at 100 $\mathrm{nm} / \mathrm{min}$ with a response time of $1 \mathrm{~s}$. Each spectrum was the average of 3 scans and was recorded in the wavelength range of $200-250 \mathrm{~nm}$ using quartz cuvette of $0.1 \mathrm{~cm}$ path length.

\section{Measurement of superoxide generation by 5 -} FU

The superoxide species $\left(\mathrm{O}_{2}{ }^{-}\right)$generation was estimated by the nitro-blue-tetrazolium (NBT) assay ${ }^{41}$. A typical assay mixture was used containing $50 \mathrm{mM}$ sodium phosphate buffer ( $\mathrm{pH} 8.0$ ), $300 \mu \mathrm{M}$ NBT, 100 $\mu \mathrm{M}$ EDTA and $0.06 \%$ Triton-X-100 and $\alpha_{2} \mathrm{M}(20$ $\mu \mathrm{M})$ treated with varying concentration of 5-FU (10 $-50 \mu \mathrm{M})$. The absorbance was recorded at $560 \mathrm{~nm}$ at different time intervals, against a blank which was without 5-FU.

\section{Fluorescence microscopy}

Fluorescence microscopy was utilized to determine the formation of reactive oxygen species (ROS). De- 
termination of ROS was performed using the dichlorofluorescein (DCF) method ${ }^{\mathbf{4 2}}$. Protein was preincubated with quercetin for $1 \mathrm{hr}$, treated with 5-FU and incubated in the presence of white light. Then the sample was incubated with $10 \mu \mathrm{M}$ dichloro-dihydrofluorescein diacetate (DCFH-DA) for $1 \mathrm{hr}$ at $37^{\circ} \mathrm{C}$. The treated protein was placed on glass coverslips and visualized under a fluorescent microscope at 40 $\mathrm{x}$ magnification.

\section{Statistical Analysis}

Results were shown as the mean and the standard deviation ( $S D$ values, with $n=3$ as the number of independent experiments.

\section{RESULTS}

\section{Antiproteinase activity}

The activity assay of native $\alpha_{2} \mathrm{M}$ with varying concentration of 5-FU was measured in order to check the functional status of the protein. Firstly, we measured the antiproteinase activity of protein incubated with the drug in the presence of white light. Our results show that the activity of protein decreases with increasing concentration of 5-FU $(10-50 \mu \mathrm{M})$. According to Figure 1a, the residual activity was found to be $87 \%$ at $10 \mu \mathrm{M} 5$-FU. When the concentration of the drug $(50 \mu \mathrm{M})$ was increased, the remaining activity was found to be $48 \%$. According to previous studies, 5 -FU is known to generate free radicals in the presence of white light ${ }^{43}$. Therefore, the anti-proteolytic potential of the protein was compromised, which may be due to the formation of free radicals by the drug leading to changes in the functionality of the protein. We measured the protective effect of quercetin against the toxicity induced by 5 $\mathrm{FU}$, since it is a flavonoid which is known to scavenge free radicals ${ }^{\mathbf{4 4}}$. When the protein was preincubated with quercetin and then treated with 5-FU in the presence of light the resultant activity decreased, but not as much compared to 5-FU alone. Our results suggest that the residual inhibitory activity at $50 \mu \mathrm{M} 5$ FU was 59\% when the protein was preincubated with quercetin (Figure 1b). Therefore, quercetin provides a protective role against 5 -FU since it may scavenge free radicals that are generated by the drug.

\section{Intrinsic fluorescence measurements}

Intrinsic fluorescence is mainly used to determine the conformational changes in the native form of the protein. The fluorescence spectra were recorded for the protein $(20 \mu \mathrm{M})$ with increasing concentration of 5 FU $(10-50 \mu \mathrm{M})$. The protein was excited at $280 \mathrm{~nm}$ and emission spectra were taken in the range $300-400$ $\mathrm{nm}$. The emission maximum $(\lambda \max / \lambda \mathrm{em})$ for native $\alpha_{2} \mathrm{M}$ was found to be $328 \mathrm{~nm}$, as shown in Figure 2a. It is quite clear from the figure that with increasing concentration of 5-FU, the fluorescence intensity decreases continuously with a blue shift of $3 \mathrm{~nm}$. The decrease in the intensity is due to the quenching in fluorescence due to the interaction between the protein and the drug. The quenching occurs mainly due to three intrinsic fluorophores in the protein i.e., phenylalanine, tyrosine and tryptophan ${ }^{45}$. The change in the fluorescence intensity can be correlated to the change in the structure of $\alpha_{2} \mathrm{M}$ as the ligand binds to it ${ }^{46}$, which may also alter the function of the protein. Many in vitro studies suggest that quercetin can reduce the toxicity induced by anticancer drugs and provide a protective effect against free radical induced damage ${ }^{31}$. To evaluate the protective effect of quercetin against 5-FU-induced toxicity on $\alpha_{2} \mathrm{M}$, intrinsic fluorescence was recorded. The protein was first preincubated with quercetin and then treated with the drug in the presence of white light, intrinsic fluorescence was then recorded. As the results suggest, with varying concentrations of 5-FU the fluorescence intensity decreases, but when the protein was preincubated with quercetin, less quenching occurs (Figure 2b). So, we can conclude that in the presence of quercetin, $\alpha_{2} \mathrm{M}$ regains its native structure which was damaged by the drug.

\section{Synchronous fluorescence analysis}

Synchronous fluorescence was performed to study the changes in the molecular environment in the vicinity of the chromophore. The spectral analysis provides information about the conformational changes around the tyrosine and tryptophan residues of the protein. The effect of fluorescence analysis of 5-FU on $\alpha_{2} \mathrm{M}$ is shown in Figure 3. With the addition of drug, there was a decrease in the fluorescence intensity with a shifting of emissions towards a longer wavelength from 341 to $344 \mathrm{~nm}$ for tryptophan residues and towards a shorter wavelength from 309 to $305 \mathrm{~nm}$ for tyrosine residues. This decrease in the fluorescence intensity with varying concentration of 5-FU suggests changes in the surrounding microenvironment around tyrosine and tryptophan residues with a decrease in hydrophobicity around both residues ${ }^{47}$.

\section{UV absorption spectroscopy}

UV spectra was analyzed to determine the structural change in the native protein and to study the formation of a complex between protein and ligand ${ }^{48}$. It 

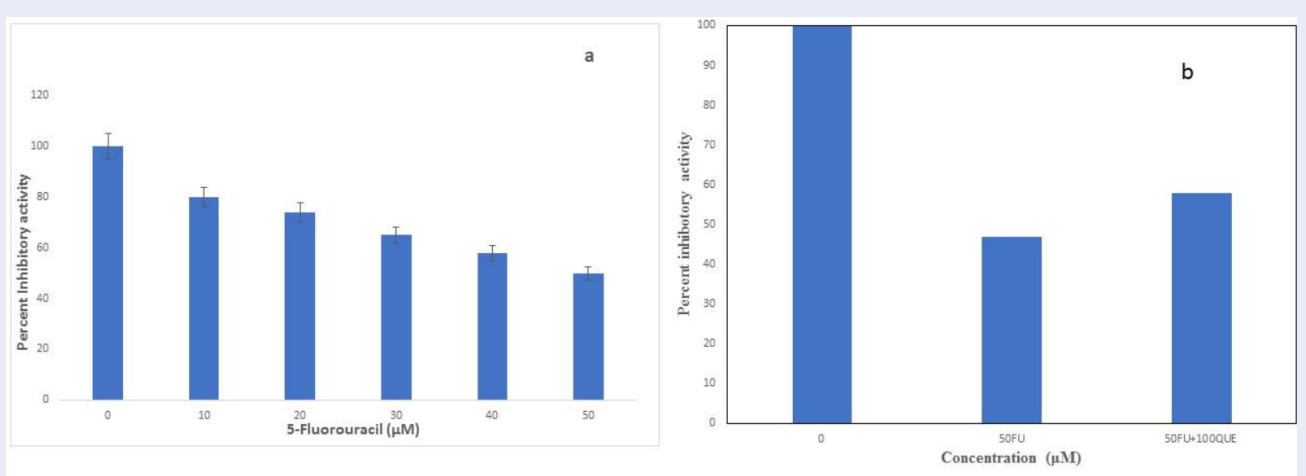

Figure 1: Percent inhibitory activity of $\alpha 2 \mathrm{M}$ (a) $\alpha 2 \mathrm{M}$ was incubated with increasing concentration of 5-FU in light assayed for antiproteolytic activity (b) $\alpha 2 \mathrm{M}$ was preincubated with quercetin $(100 \mu \mathrm{M})$ and then incubated with 5-FU $(50 \mu \mathrm{M})$ in visible light then assayed for antiproteolytic activity (Paired $\mathbf{t}$ for conc \%IA. 95\%. Cl for mean difference: $-84.2276,-8.1058$. T-test of mean difference $=0$ (vs not $=0)$ : $t$-value $=-3.12$, p-value $=0.026$ )

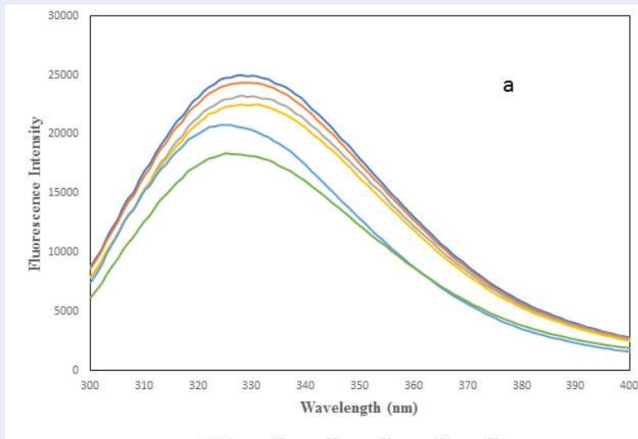

$-40-50$

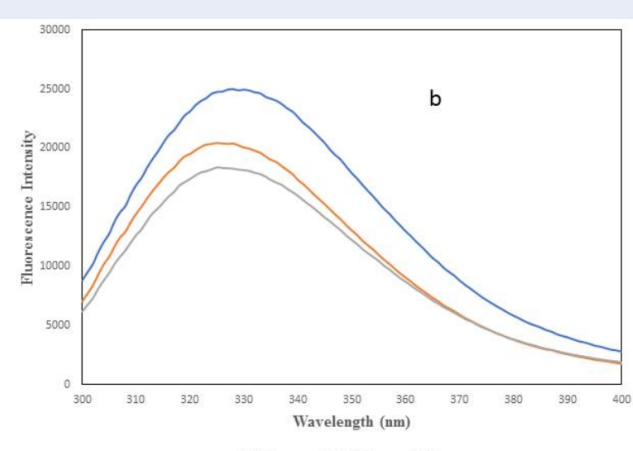

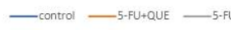

Figure 2: Fluorescence spectroscopy (a) fluorescence spectra of native $\alpha_{2} \mathbf{M}$ and 5-FU treated in light (b) fluorescence spectra of $\alpha_{2} \mathrm{M}$ preincubated with quercetin (100 $\left.\mu \mathrm{M}\right)$ and then treated with 5-FU (50 $\left.\mu \mathrm{M}\right)$ in the presence of visible white light.

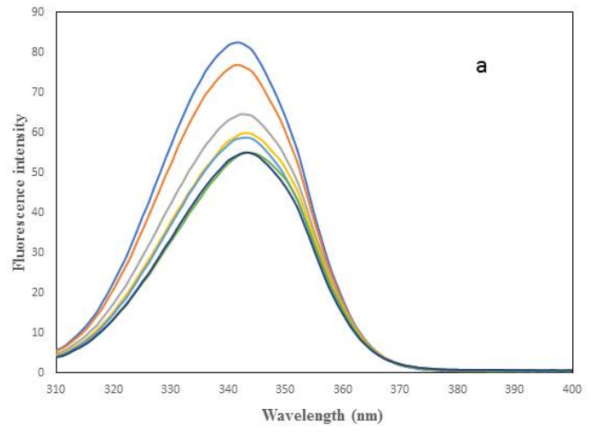

$\square^{c}-^{6}-^{8}-^{10}-^{12}-^{14} \longrightarrow^{1}$

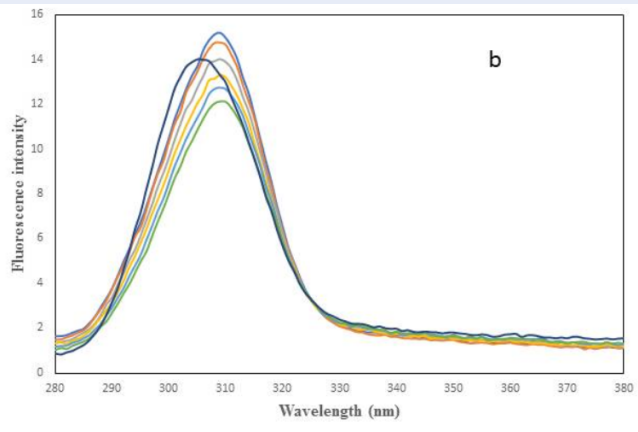

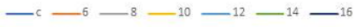

Figure 3: Synchronous fluorescence spectra of $\alpha_{2} M$ with $\lambda=15 \mathrm{~nm}(A)$ and $\lambda=60 \mathrm{~nm}$ (B) in the presence of 5-FU (6 - $16 \mu \mathrm{M})$. 

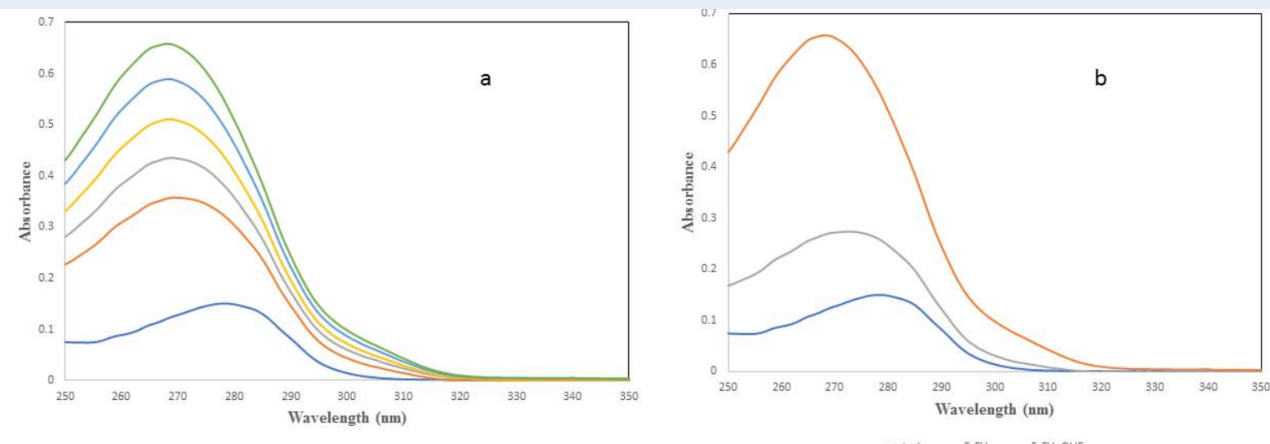

- control $-10-20-30-^{40}-50$

Figure 4: UV spectroscopy (a) $\alpha_{2} \mathbf{M}$ was incubated with increasing concentration of 5-FU (10 - $\left.50 \mu \mathrm{M}\right)$ in light; (b) $\alpha_{2}$ M was preincubated with quercetin (100 $\mu \mathrm{M}$ ) than incubated with 5-FU (50 $\left.\mu \mathrm{M}\right)$.

is a classical technique to determine the modification in the microenvironment of amino acid residues, particularly tryptophan, resulting in the change in the spectra or a shift in maximum absorbance/lambda $\max \left(\lambda_{\max }\right)^{45}$. To examine the change in the native structure of $\alpha_{2} \mathrm{M}$ with varying concentration of 5 -FU, spectra was recorded between $250-350 \mathrm{~nm}$ (Figure 4a). As shown in Figure 4, the $\lambda_{\text {max }}$ for native $\alpha_{2} \mathrm{M}$ was found to be $278 \mathrm{~nm}$, but with increasing concentration of 5-FU, the absorbance increases and a blue shift $(10 \mathrm{~nm})$ was observed. The blue shift indicates that the interaction of drug with $\alpha_{2}$ M causes some structural changes in the native form of protein. It is well-known that 5-FU forms free radicals in the presence of white light that may cause damage or change in the protein. So, quercetin was used as a protective agent to scavenge the free radicals formed by the drug. $\alpha_{2} \mathrm{M}$ was preincubated with quercetin and then treated with 5-FU in the presence of light. When $\alpha_{2}$ M was preincubated with quercetin, the effect of drug was less compared to drug alone and $\lambda_{\text {max }}$ was found to be $275 \mathrm{~nm}$ (Figure 4b). Our results suggest that quercetin scavenges free radicals formed by drug and prevents oxidative damage and/or restores the native structure of protein.

\section{Measurement of superoxide generation by} 5-FU

5-FU was subjected for photo-illumination in order to measure the free radical(s) generated by it. The free radical generated by drug was measured by the NBT reduction assay.Figure 5a depicts the generation of superoxide anions $\left(\mathrm{O}_{2}{ }^{-}\right)$with increasing concentration of 5 -FU $(10-100 \mu \mathrm{M}) . \alpha_{2} \mathrm{M}$ was preincubated with quercetin $(100 \mu \mathrm{M})$ and then exposed to 5 -FU for $1 \mathrm{hr}$ in light. According to Figure 5b, quercetin decrease the formation of superoxide anion as compared to 5-FU alone. So, the results suggest that quercetin has antioxidant activity against the formation of free radicals by 5 -FU.

\section{FTIR spectroscopy}

The FTIR spectroscopy was utilized to determine the change in the secondary structure of protein. Amide I band was analyzed as it is the most important protein band for the analysis of possible structural changes. The amide I band displays in the wave number range $1600-1700 \mathrm{~cm}^{-1}$ governed by the stretching of the $\mathrm{C}=\mathrm{O}(70-85 \%)$ and minor contribution of $\mathrm{C}-\mathrm{N}$ groups $(10-20 \%)$.Figure 6 shows the FTIR spectra of native $\alpha_{2} \mathrm{M}$ along with 5-FU and quercetin. The amide I band for native $\alpha_{2} \mathrm{M}$ was centered at around $1635 \mathrm{~cm}^{-1}$ which is characteristic of $\beta$-sheet structure $^{38}$. However, upon incubation with 5-FU, the amide I band was at $1635 \mathrm{~cm}^{-1}$, but the intensity decreases with varying concentration which implies the loss of protein native conformation. The native conformation of $\alpha_{2} \mathrm{M}$ is lost, which affects the functional activity of the antiproteinase inhibitor suggesting that 5 -FU causes structural changes in the native conformation of protein, which was confirmed by the antiproteinase activity results. In order to determine the preventive effect of quercetin, the protein was incubated with 5-FU. Figure 6 shows that the band for $\alpha_{2} \mathrm{M}$ preincubated with quercetin was found to be close to that of native protein. Hence, quercetin scavenges the free radicals from the drug and provides a protective role against the oxidative modification of $\alpha_{2} \mathrm{M}$.

\section{CD measurements}

CD spectroscopy was performed to analyse the structural transitions in the structure of protein since it 

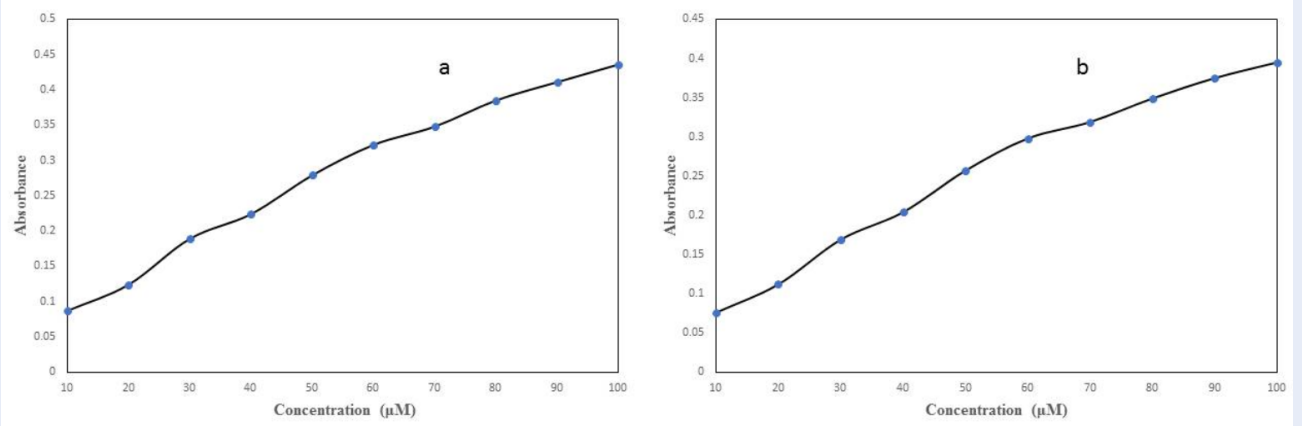

Figure 5: Generation of superoxide anion (a) 5-FU (10 - $10 \mu \mathrm{M})$ in the presence of light (b) $\alpha_{2} \mathrm{M}$ was preincubated with quercetin $(100 \mu \mathrm{M})$ and then exposed to 5 -FU $(10-10 \mu \mathrm{M})$ in light for $1 \mathrm{hr}$.

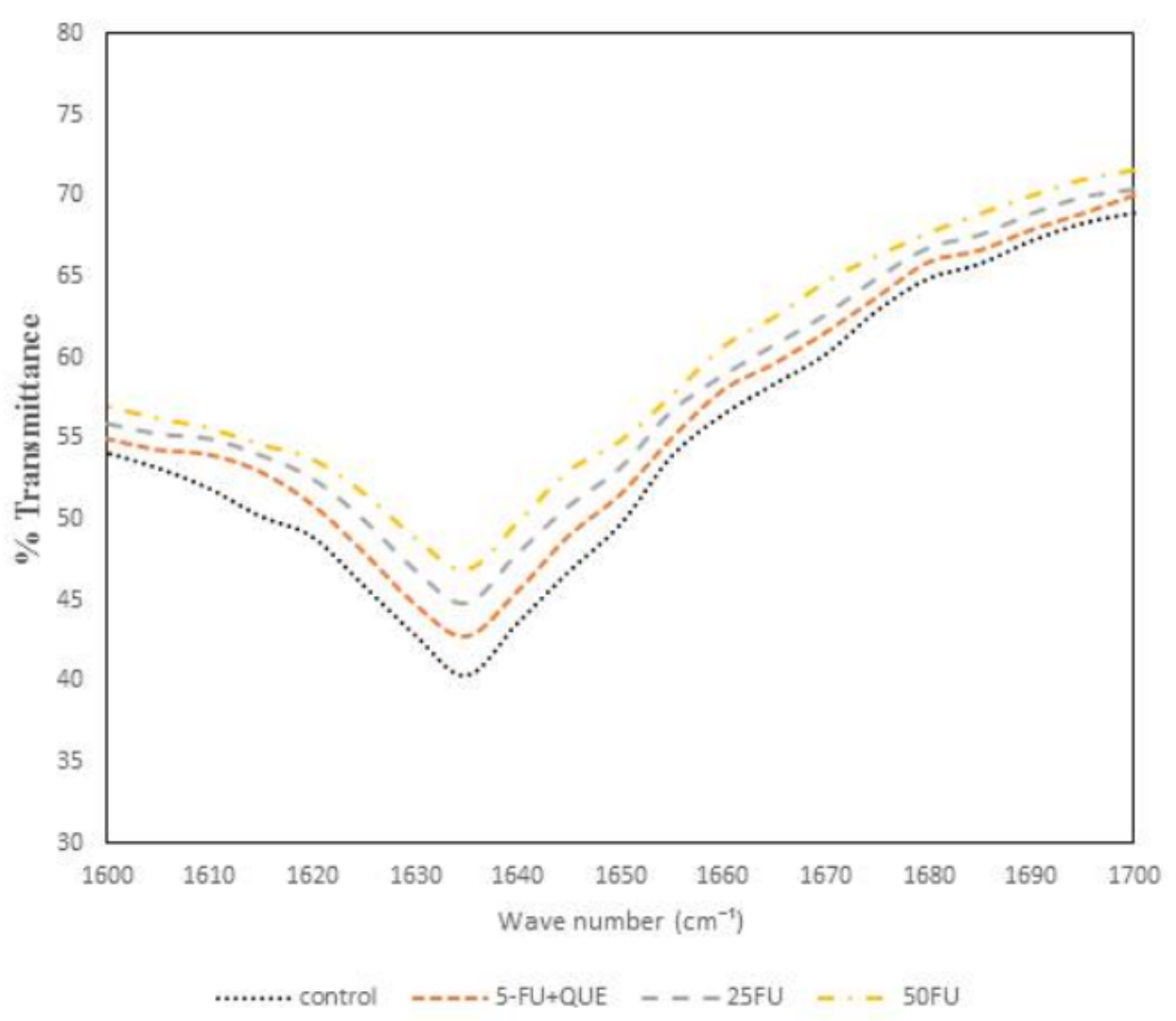

Figure 6: FT-IR spectra of native $\alpha_{2} \mathrm{M}$ and treated with 5-FU and quercetin in light. 


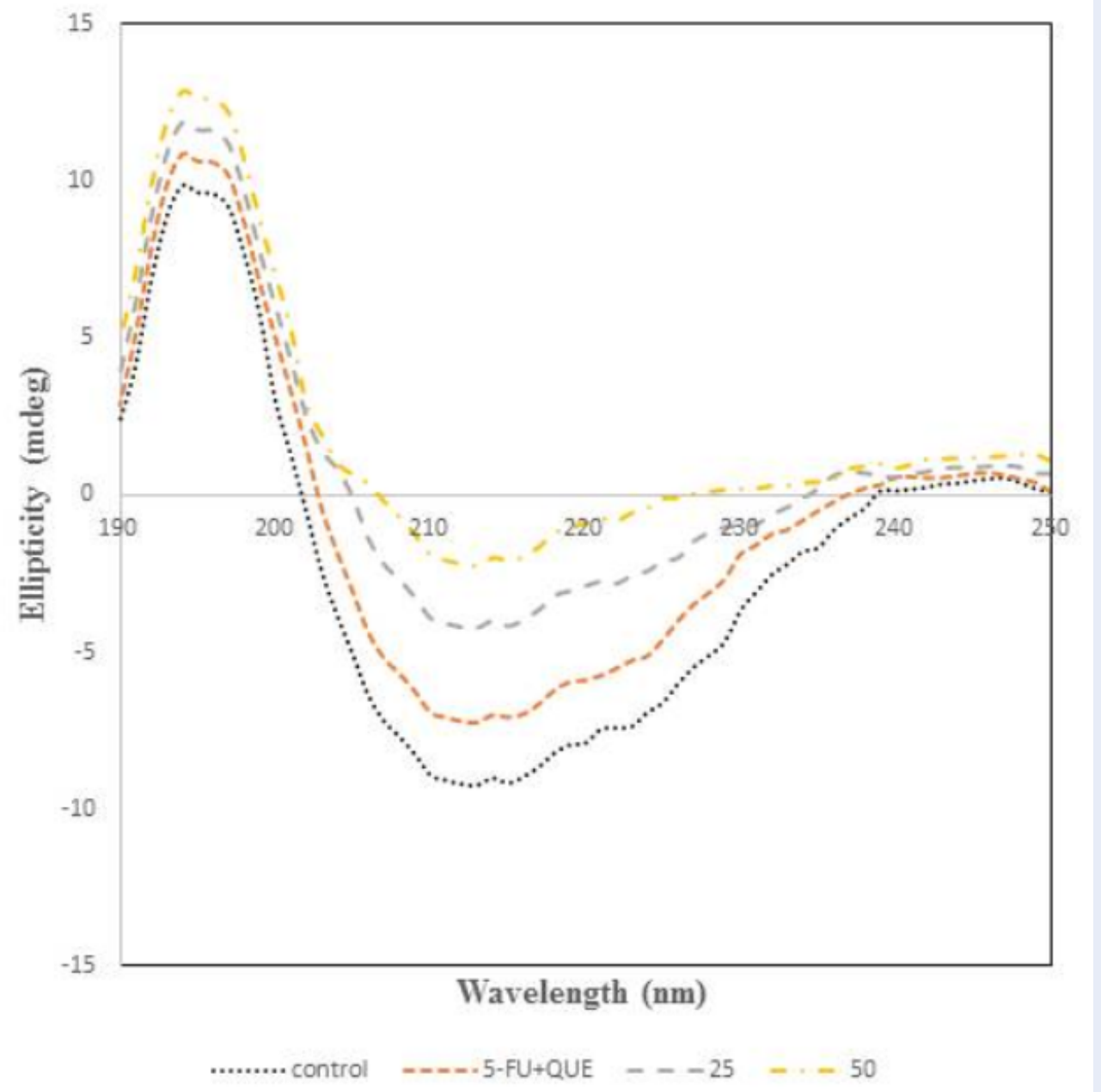

Figure 7: Far-UV circulardichroism spectra of native $\alpha_{2} \mathbf{M}$, treated with 5-FU and quercetin.
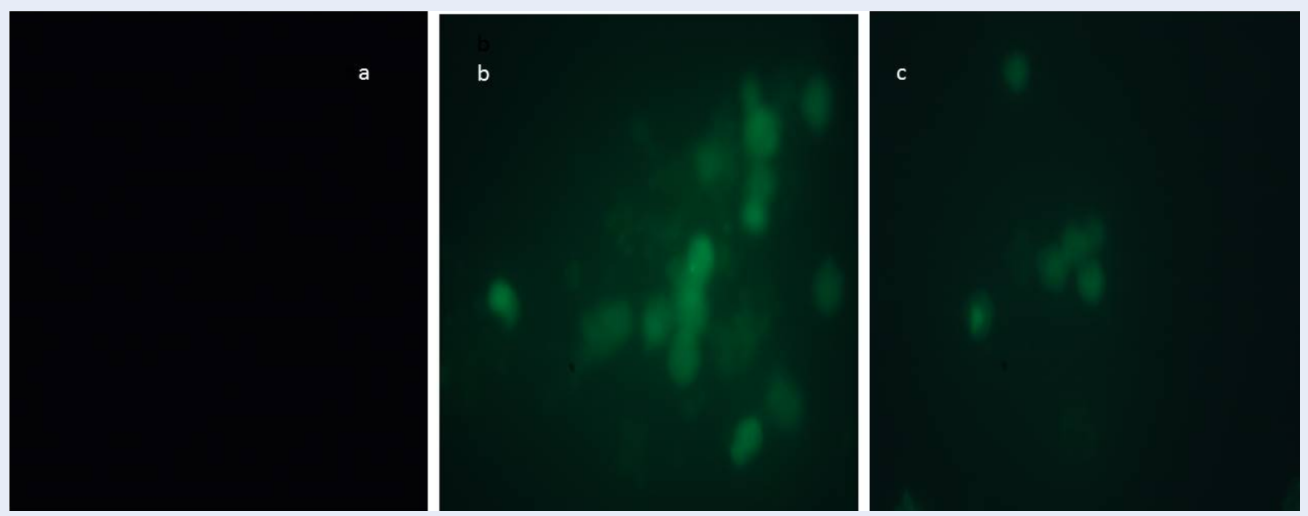

Figure 8: Representative fluorescent microscopic images (a) native $\alpha_{2} \mathbf{M}$, (b) treated with 5-Fluorouracil (50 $\mu \mathrm{M})$ and (c) treated with quercetin $(100 \mu \mathrm{M})$ and 5-FU (50 $\mu \mathrm{M})$. 
gives information regarding the secondary structural changes ${ }^{49-51}$. The CD spectra of $\alpha_{2} \mathrm{M}$ incubated with 5-FU and quercetin are shown in Figure 7. The peak of native protein was found at $215 \mathrm{~nm}$ which is a characteristic feature of $\beta$-sheet structure ${ }^{38,39}$. However, varying the concentration of 5-FU leads to changes in the far UV-CD spectra resulting in the increase, which suggests the loss of $\beta$-sheet content in native $\alpha_{2} \mathrm{M}$. So, the formation of free radicals by the drug causes structural distortion in the native form of protein. Thus, it can be said that the loss in $\beta$-sheet content of the protein alters the biological activity of the protein. In order to identify the protective effect of quercetin, it was incubated with $\alpha_{2} \mathrm{M}$ and 5-FU and it was found that $\alpha_{2} \mathrm{M}$ preincubated with quercetin shows spectra very similar to that of native protein.

\section{Fluorescence microscopy}

The effect of drug on the native protein and effect of quercetin on 5-FU treated protein was examined. As depicted inFigure 8a, the native protein shows no fluorescence which indicates no free radicals are present in the sample. 5-FU is known to form free radicals in the presence of white light which can damage the native conformation of protein. When $\alpha_{2} \mathrm{M}$ was incubated with 5 -FU $(50 \mu \mathrm{M})$ it showed bright fluorescence representing the production of free radicals (Figure 8b). When $\alpha_{2} \mathrm{M}$ was preincubated with quercetin and then treated with 5-FU, a weaker fluorescence was observed, which shows a reduction in the formation of free radicals (Figure 8c).

\section{DISCUSSION}

The flavonoids are the polyphenolic compounds of plant origin found in vegetables, fruits, red wine, tea, etc. and possess antioxidant and anti-inflammatory properties $^{28-31}$. Quercetin provides a protective effect against free radicals induced oxidative stress and possesses many beneficial effects against liver disease that may be caused by the endotoxins ${ }^{32-37}$. In the present study, the interaction of 5-FU with $\alpha_{2} \mathrm{M}$ was examined for the first time. Quercetin was incubated with 5-FU treated $\alpha_{2} \mathrm{M}$ and antiproteinase activity assay was performed to measure the functional activity of the protein. 5-FU causes structural and functional changes in the native conformation of $\alpha_{2} \mathrm{M}$ and quercetin was used to prevent the toxic effects of the drug. The results obtained from the intrinsic fluorescence and absorption spectroscopy show that 5-FU causes conformation changes in the native form of protein due to the formation of free radicals and quercetin provided a protective role. CD and FTIR spectroscopy were used to analyze the secondary structural changes in the protein treated with the drug and it regained its native conformation in the presence of quercetin. Fluorescence microscopy was analyzed to study the formation of free radicals by 5 FU, the results show that 5-FU forms free radicals and quercetin provides a scavenging role. On the other hand, when the $\alpha_{2} \mathrm{M}-5 \mathrm{FU}$ mixture was treated with quercetin, the protein regains its native conformation. Our study provides an insight into the 5-FU- $\alpha_{2} \mathrm{M}$ interaction and the scavenging role of quercetin.

\section{CONCLUSIONS}

In the present study, we reported the interaction of 5FU with $\alpha 2 \mathrm{M}$ and the protective effect of quercetin against 5-FU induced modification of $\alpha 2 \mathrm{M}$. Various biochemical and biophysical methods were employed to determine the binding between $\alpha 2 \mathrm{M}-5-\mathrm{FU}$ and the protective effect of quercetin on 5 -FU induced modification of $\alpha 2 \mathrm{M}$. Photoilluminated 5-FU produces ROS which compromises the structural and functional integrity of $\alpha 2 \mathrm{M}$. Quercetin quenches the ROS produced by 5-FU and helps the protein to maintain its native conformation. Therefore, we demonstrated the protective effect of quercetin for the first time against the toxicity induced by $5-\mathrm{FU}$ on $\alpha 2 \mathrm{M}$.

\section{ABBREVIATIONS}

5-FU: 5-fluorouracil, $\alpha_{2}$ M: alpha-2-macroglobulin, CD: circular dichroism, FTIR: fluorescence transform infra-red spectroscopy, ROS: reactive oxygen species

\section{ACKNOWLEDGMENTS}

The authors are grateful to the Department of Biochemistry, Aligarh Muslim University, Aligarh for the facilities provided. The University Grants Commission (UGC), New Delhi, is also acknowledged for funding. We wish to thank the reviewers for their opinion, suggestions and recommendation.

\section{AUTHOR'S CONTRIBUTIONS}

SSA: collected data and performed analysis; acquisition, analysis and interpretation of data; drafted the manuscript; HA: wrote the paper; drafted the manuscript; critically revised the manuscript; SA: performed the analysis; FHK: conceived, conceptualized and designed the study; gave final approval.

\section{FUNDING}

The University Grants Commission (UGC), New Delhi. 


\section{AVAILABILITY OF DATA AND MATERIALS}

Data and materials used and/or analyzed during the current study are available from the corresponding author on reasonable request.

\section{ETHICS APPROVAL AND CONSENT TO PARTICIPATE}

This study was conducted in accordance with the amended Declaration of Helsinki. The institutional review board approved the study, and all participants provided written informed consent.

\section{CONSENT FOR PUBLICATION}

Not applicable.

\section{COMPETING INTERESTS}

The authors declare that they have no competing interests.

\section{REFERENCES}

1. Peters GJ, Laurensse E, Leyva A, Lankelma J, Pinedo HM. Sensitivity of human, murine, and rat cells to 5 -fluorouracil and 5 '-deoxy-5-fluorouridine in relation to drug-metabolizing enzymes. Cancer Research. 1986;46(1):20-8. PMID: 2415245.

2. Zhang N, Yin Y, Xu SJ, Chen WS. 5-Fluorouracil: mechanisms of resistance and reversal strategies. Molecules (Basel, Switzerland). 2008;13(8):1551-69. PMID: 18794772. Available from: $10.3390 /$ molecules13081551.

3. Morris SM. The genetic toxicology of 5-fluoropyrimidines and 5-chlorouracil. Mutation Research. 1993;297(1):39-51. PMID: 7686272. Available from: 10.1016/0165-1110(93)90006-9.

4. Wang X, Lin J, Zhang X, Liu Q, Xu Q, Tan RX. 5-Fluorouracilcisplatin adducts with potential antitumor activity. Journal of Inorganic Biochemistry. 2003;94(1-2):186-92. PMID: 12620690. Available from: 10.1016/S0162-0134(02)00618-9.

5. Lamberti M, Porto S, Marra M, Zappavigna S, Grimaldi A, Feola D. 5-Fluorouracil induces apoptosis in rat cardiocytes through intracellular oxidative stress. Journal of Experimental \{\&amp;\}amp; Clinical Cancer Research. 2012;31(1):60. PMID: 22812382. Available from: 10.1186/1756-9966-31-60.

6. Pendekal MS, Tegginamat PK. Development and characterization of chitosan-polycarbophil interpolyelectrolyte complexbased 5-fluorouracil formulations for buccal, vaginal and rectal application. Daru : Journal of Faculty of Pharmacy, Tehran University of Medical Sciences. 2012;20(1):67. PMID: 23351403. Available from: 10.1186/2008-2231-20-67.

7. Steger F, Hautmann MG, Kölbl O. 5-FU-induced cardiac toxicityunderestimated problem in radiooncology? Radiation Oncology (London, England). 2012;7(1):212. PMID: 23241239. Available from: 10.1186/1748-717X-7-212.

8. Kosmas C, Kallistratos MS, Kopterides P, Syrios J, Skopelitis H, Mylonakis N. Cardiotoxicity of fluoropyrimidines in different schedules of administration: a prospective study. Journal of Cancer Research and Clinical Oncology. 2008;134(1):75-82. PMID: 17636329. Available from: 10.1007/s00432-007-0250-9.

9. Labianca R, Beretta G, Clerici M, Fraschini P, Luporini G. Cardiac toxicity of 5-fluorouracil: a study on 1083 patients. Tumori. 1982;68(6):505-10. PMID: 7168016. Available from: 10.1177/ 030089168206800609.

10. Jensen SA, Sørensen JB. Risk factors and prevention of cardiotoxicity induced by 5 -fluorouracil or capecitabine. Cancer Chemotherapy and Pharmacology. 2006;58(4):487-93. PMID: 16418875. Available from: 10.1007/s00280-005-0178-1.
11. Mosseri M, Fingert HJ, Varticovski L, Chokshi S, Isner JM. In vitro evidence that myocardial ischemia resulting from 5 -fluorouracil chemotherapy is due to protein kinase Cmediated vasoconstriction of vascular smooth muscle. Cancer Research. 1993;53(13):3028-33. PMID: 8391384.

12. Stewart T, Pavlakis N, Ward M. Cardiotoxicity with 5fluorouracil and capecitabine: more than just vasospastic angina. Internal Medicine Journal. 2010;40(4):303-7. PMID: 20529041. Available from: 10.1111/j.1445-5994.2009.02144.x.

13. Saif MW, Shah MM, Shah AR. Fluoropyrimidine-associated cardiotoxicity: revisited. Expert Opinion on Drug Safety. 2009;8(2):191-202. PMID: 19309247. Available from: 10.1517/ 14740330902733961.

14. Sorrentino MF, Truesdell AG. 5-Fluorouracil-induced coronary thrombosis: A case report and review of the literature. Journal of Cardiology Cases. 2012;6(1):e20-2. PMID: 30532939. Available from: 10.1016/j.jccase.2012.03.011.

15. Rehman AA, Ahsan $H$, Khan FH. Identification of a new alpha2-macroglobulin: multi-spectroscopic and isothermal titration calorimetry study. International Journal of Biological Macromolecules. 2016;83:366-75. PMID: 26608004. Available from: 10.1016/j.ijbiomac.2015.11.043.

16. Barrett AJ, Brown MA, Sayers CA. The electrophoretically 'slow' and 'fast' forms of the alpha 2-macroglobulin molecule. The Biochemical Journal. 1979;181(2):401-18. PMID: 91367. Available from: 10.1042/bj1810401.

17. Sottrup-Jensen L. Alpha-macroglobulins: structure, shape, and mechanism of proteinase complex formation. The Journal of Biological Chemistry. 1989;264(20):11539-42. PMID: 2473064. Available from: 10.1016/S0021-9258(18)80094-1.

18. Buresova V, Hajdusek O, Franta Z, Sojka D, Kopacek P. IrAMAn $\alpha 2$-macroglobulin from the hard tick Ixodes ricinus: characterization and function in phagocytosis of a potential pathogen Chryseobacterium indologenes. Developmental and Comparative Immunology. 2009;33(4):489-98. PMID: 18948134. Available from: 10.1016/j.dci.2008.09.011.

19. Raymond WW, Su S, Makarova A, Wilson TM, Carter MC, Metcalfe DD. $\alpha$ 2-macroglobulin capture allows detection of mast cell chymase in serum and creates a reservoir of angiotensin II-generating activity. Journal of Immunology (Baltimore, Md: 1950). 2009;182(9):5770-7. PMID: 19380825. Available from: 10.4049/jimmunol.0900127.

20. Ma H, Wang B, Zhang J, Li F, Xiang J. Multiple forms of alpha-2 macroglobulin in shrimp Fenneropenaeus chinesis and their transcriptional response to WSSV or Vibrio pathogen infection. Developmental and Comparative Immunology. 2010;34(6):677-84. PMID: 20105438. Available from: 10.1016/ j.dci.2010.01.014.

21. Lim W, Jeong W, Kim JH, Lee JY, Kim J, Bazer FW. Differential expression of alpha 2 macroglobulin in response to dietylstilbestrol and in ovarian carcinomas in chickens. Reproductive Biology and Endocrinology. 2011;9(1):137. PMID: 21978460. Available from: 10.1186/1477-7827-9-137.

22. Neves D, Estrozi LF, Job V, Gabel F, Schoehn G, Dessen A. Conformational states of a bacterial $\alpha 2$-macroglobulin resemble those of human complement C3. PLoS One. 2012;7(4):e35384. PMID: 22530012. Available from: 10.1371/journal.pone. 0035384.

23. Borth W. Alpha 2-macroglobulin, a multifunctional binding protein with targeting characteristics. The FASEB Journal. 1992;6(15):3345-53. PMID: 1281457. Available from: 10.1096/fasebj.6.15.1281457.

24. Kratzsch J, Selisko T, Birkenmeier G. Identification of transformed alpha 2-macroglobulin as a growth hormone-binding protein in human blood. The Journal of Clinical Endocrinology and Metabolism. 1995;80(2):585-90. PMID: 7531714.

25. Khan SA, Khan FH. Oxidized caprine alpha-2-macroglobulin: damaged but not completely dysfunctional. Biochimica et Biophysica Acta. 2004;1674(2):139-48. PMID: 15374618.

26. Lin Z, Lo A, Simeone DM, Ruffin MT, Lubman DM. An Nglycosylation analysis of human alpha-2-macroglobulin using 
an integrated approach. Journal of Proteomics \{\&amp; \}amp; Bioinformatics. 2012;5:127-34. PMID: 23028207. Available from: $10.4172 / \mathrm{jpb} .1000224$.

27. Rehman AA, Ahsan H, Khan FH. $\alpha$-2-Macroglobulin: a physiological guardian. Journal of Cellular Physiology. 2013;228(8):1665-75. PMID: 23086799. Available from: 10. $1002 /$ jcp. 24266 .

28. Kao TK, Ou YC, Lin SY, Pan HC, Song PJ, Raung SL. Luteolin inhibits cytokine expression in endotoxin/cytokinestimulated microglia. The Journal of Nutritional Biochemistry. 2011;22(7):612-24. PMID: 21036586. Available from: 10.1016/j.jnutbio.2010.01.011.

29. Kao TK, Ou YC, Raung SL, Lai CY, Liao SL, Chen CJ. Inhibition of nitric oxide production by quercetin in endotoxin/cytokinestimulated microglia. Life Sciences. 2010;86(9-10):315-21. PMID: 20060843. Available from: 10.1016/j.lfs.2009.12.014.

30. Fang YZ, Yang S, Wu G. Free radicals, antioxidants, and nutrition. Nutrition (Burbank, Los Angeles County, Calif). 2002;18(10):872-9. PMID: 12361782. Available from: 10.1016/ S0899-9007(02)00916-4.

31. Çelik H, Arinç E. Evaluation of the Protective Effects of Quercetin, Rutin, Resveratrol, Naringenin and Trolox Against Idarubicin-Induced DNA Damage. Journal of Pharmacy \{\&amp;\}amp; Pharmaceutical Sciences. 2010;13(2):231-41. PMID: 20816008. Available from: 10.18433/J3S01G.

32. Lin SY, Wang YY, Chen WY, Chuang YH, Pan PH, Chen CJ. Beneficial effect of quercetin on cholestatic liver injury. The Journal of Nutritional Biochemistry. 2014;25(11):1183-95. PMID: 25108658. Available from: 10.1016/j.jnutbio.2014.06.003.

33. Bharrhan S, Chopra K, Arora SK, Toor JS, Rishi P. Downregulation of NF- $\kappa$ B signalling by polyphenolic compounds prevents endotoxin-induced liver injury in a rat model. Innate Immunity. 2012;18(1):70-9. PMID: 21239456. Available from: $10.1177 / 1753425910393369$.

34. Choi KC, Chung WT, Kwon JK, Yu JY, Jang YS, Park SM. Inhibitory effects of quercetin on aflatoxin B1-induced hepatic damage in mice. Food and Chemical Toxicology. 2010;48(10):2747-53. PMID: 20621152. Available from: 10 . 1016/j.fct.2010.07.001.

35. de David C, Rodrigues G, Bona S, Meurer L, GonzálezGallego J, Tuñón MJ. Role of quercetin in preventing thioacetamide-induced liver injury in rats. Toxicologic Pathology. 2011;39(6):949-57. PMID: 21885874. Available from: $10.1177 / 0192623311418680$.

36. Domitrović R, Jakovac H, Marchesi VV, Vladimir-Kneć S, Cvijanović $O$, Tadić $Z$. Differential hepatoprotective mechanisms of rutin and quercetin in $\mathrm{CCl}(4)$-intoxicated $\mathrm{BALB} / \mathrm{CN}$ mice. Acta Pharmacologica Sinica. 2012;33(10):1260-70. PMID: 22902988. Available from: 10.1038/aps.2012.62.

37. Larson AJ, Symons JD, Jalili T, for Nutrition AS. Therapeutic potential of quercetin to decrease blood pressure: review of efficacy and mechanisms. Advances in Nutrition. 2012;3(1):3946. PMID: 22332099. Available from: 10.3945/an.111.001271.

38. Ali SS, Zia MK, Siddiqui T, Ahsan H, Khan FH. Biophysical analysis of interaction between curcumin and alpha-2macroglobulin. International Journal of Biological Macromolecules. 2019;128:385-90. PMID: 30690117. Available from: 10.1016/j.ijbiomac.2019.01.136.

39. Ali SS, Zia MK, Siddiqui T, Khan FH. Binding interaction of sheep alpha-2-macroglobulin and tannic acid: A spectroscopic and thermodynamic study. Spectrochimica Acta Part
A: Molecular and Biomolecular Spectroscopy. 2018;204:74853. PMID: 30007881 . Available from: 10.1016/j.saa.2018.06.024.

40. Marcon G, Plakoutsi G, Canale C, Relini A, Taddei N, Dobson CM. Amyloid formation from HypF-N under conditions in which the protein is initially in its native state. Journal of Molecular Biology. 2005;347(2):323-35. PMID: 15740744. Available from: 10.1016/j.jmb.2005.01.034.

41. Choi HS, Kim JW, Cha YN, Kim C. A quantitative nitroblue tetrazolium assay for determining intracellular superoxide anion production in phagocytic cells. Journal of Immunoassay \{\&amp;\}amp; Immunochemistry. 2006;27(1):31-44. PMID: 16450867. Available from: 10.1080/15321810500403722.

42. Keller A, Mohamed A, Dröse S, Brandt U, Fleming I, Brandes RP. Analysis of dichlorodihydrofluorescein and dihydrocalcein as probes for the detection of intracellular reactive oxygen species. Free Radical Research. 2004;38(12):1257-67. PMID: 15763950. Available from: 10.1080/10715760400022145.

43. Husain E, Chibber S, Naseem I. Amelioration of 5-FU induced toxicity by using RF under white light: An in vitro study. Integr Pharm Toxicol Genotoxicol. 2015;1(1):43-48. Available from: 10.15761/IPTG.1000108.

44. Mojzisová G, Mirossay L, Kucerová D, Kyselovivc J, Miroššay A, Mojvziš J. Protective effect of selected flavonoids on in vitro daunorubicin-induced cardiotoxicity. Phytotherapy Research. 2006;20(2):110-4. PMID: 16444662. Available from: 10.1002/ ptr.1811.

45. Chinnathambi S, Velmurugan D, Hanagata N, Aruna PR, Ganesan $\mathrm{S}$. Investigations on the interactions of 5 -fluorouracil with bovine serum albumin:Optical spectroscopic and molecular modelling studies. Journal of Luminescence. 2014;46(13):110. Available from: http://dx.doi.org/10.1016/j.jlumin.2014.01. 063.

46. Sulkowskaa A, Rownickaa J, Bojkoa B, Sulkowski W. Interaction of anticancer drugs with human and bovine serum albumin. Journal of Molecular Structure. 2003;651:133-40. Available from: 10.1016/S0022-2860(02)00642-7.

47. Hu X, Cui S, Liu J. Fluorescence studies of interaction between flavonol p-coumaroylglucoside tiliroside and bovine serum albumin. Spectrochimica Acta Part A: Molecular and Biomolecular Spectroscopy. 2010;77(2):548-53. PMID: 20615751. Available from: 10.1016/j.saa.2010.06.016.

48. Bakkialakshmi S, Chandrakala D. A spectroscopic investigations of anticancer drugs binding to bovine serum albumin. Spectrochimica Acta Part A: Molecular and Biomolecular Spectroscopy. 2012;88:2-9. PMID: 22226896. Available from: 10.1016/j.saa.2011.10.076.

49. Bannister WH, Bannister JV. J. V, Superoxide-dependent formation of hydroxyl radicals and lipid peroxidation in the presence of iron salts. Detection of 'catalytic' iron and anti-oxidant activity in extracellular fluids. The International Journal of Biochemistry. 1974;5:673-7. Available from: 10.1016/0020$711 X(74) 90052-4$.

50. Brahms S, Brahms J. Determination of protein secondary structure in solution by vacuum ultraviolet circular dichroism. Journal of Molecular Biology. 1980;138(2):149-78. PMID: 7411608. Available from: 10.1016/0022-2836(80)90282-X.

51. Chang CT, Wu CS, Yang JT. Circular dichroic analysis of protein conformation: inclusion of the beta-turns. Analytical Biochemistry. 1978;91(1):13-31. PMID: 9762080. Available from: 10.1016/0003-2697(78)90812-6. 
Ready to submit your manuscript? Choose Biomedpress and benefit from:

- Fast, convenient online submission

- Through peer-review by experienced researchers

- Rapid publication on acceptance

- Free of charge (without publication fees)

Learn more http://www.biomedpress.org/journals/
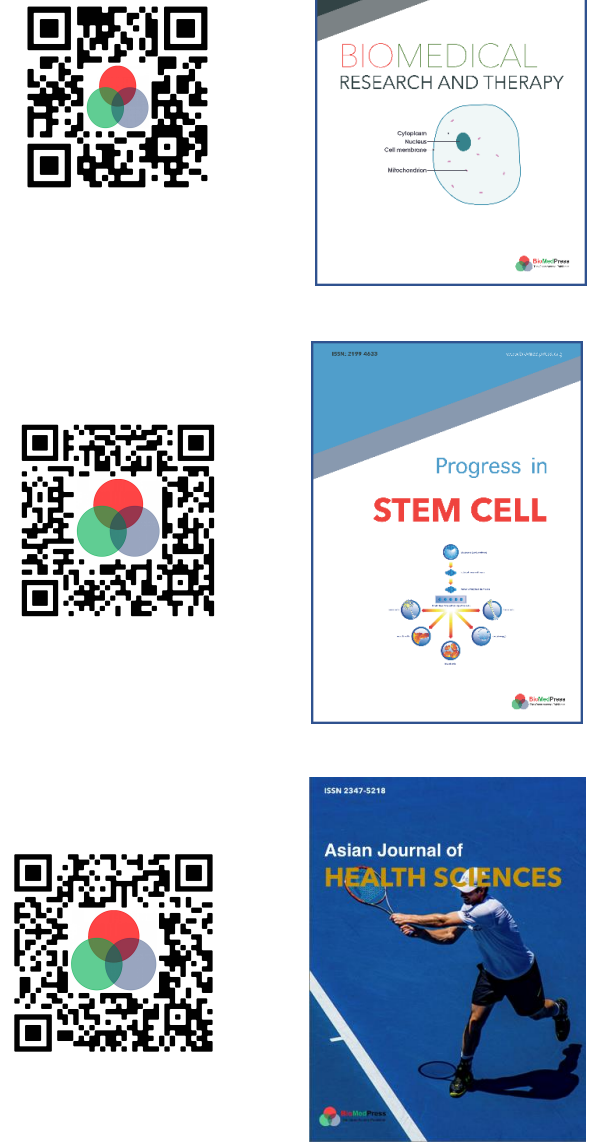

Asian Journal of Health Sciences

ISSN: 2347-5218

Indexed: Google Scholar

Acceptance Rate (2020): 72.89\%

Article Publishing Charge: Free

Submission to first editorial decision: 16.5 days

Biotechnological Research

ISSN: 2395-6763

Indexed: Google Scholar

Acceptance Rate (2020): $67.02 \%$

Article Publishing Charge: Free

Submission to first editorial decision: 28.5 days 